\title{
MAPS SHOWING LOCATIONS OF KNOWN MISSISSIPPI VALLEY-TYPE DEPOSITS AND OCCURRENCES IN THE OZARK MOUNTAINS REGION RELATIVE TO LATE CAMBRIAN SHALY LITHOFACIES AND OTHER SHALES, MISSOURI, ARKANSAS, KANSAS, AND OKLAHOMA
}

\section{By}

James R. Palmer, Missouri Division of Geology and Land Survey, and Timothy S. Hayes, U.S. Geological Survey

Prepared in cooperation with the

Missouri Department of Natural Resources, Division of Geology and Land Survey, the Arkansas Geological Commission, and the Kansas Geological Survey 


\section{CONTENTS}

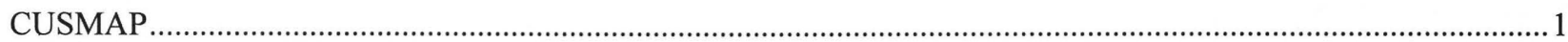

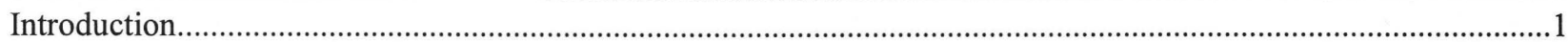

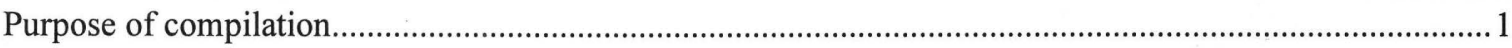

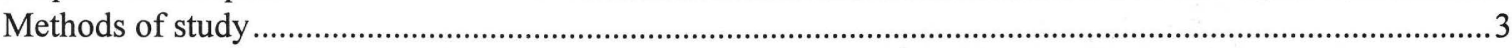

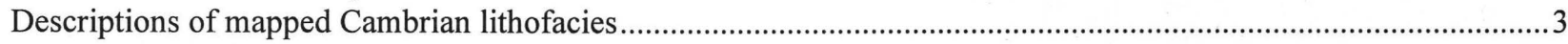

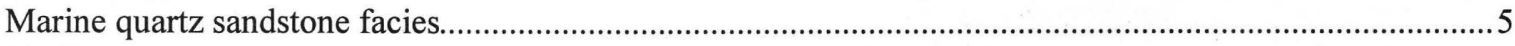

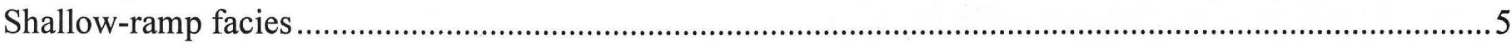

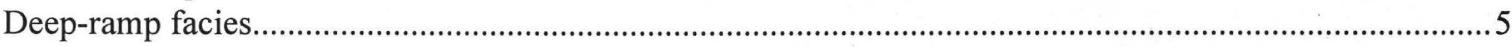

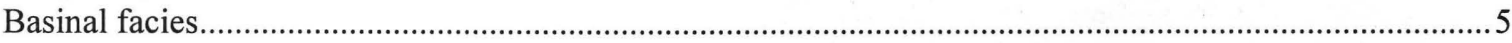

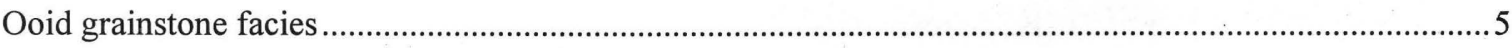

Digitate-thrombolite stromatolite boundstone facies................................................................

Planar stromatolite boundstone and burrowed carbonate mudstone facies.............................................5

Controls by sedimentary rock patterns on Mississippi Valley-type mineralization: Experience of

the Ozark Mountains CUSMAP studies ..............................................................................................

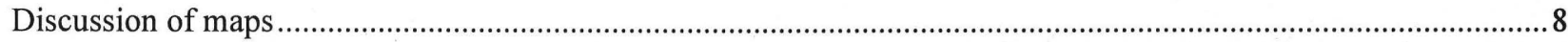

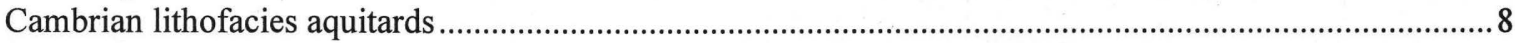

MVT deposits and occurrences relative to aquitard edges and faults.............................................

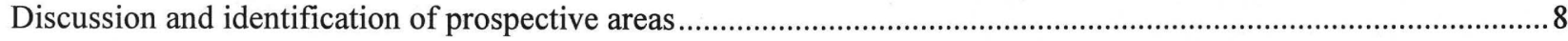

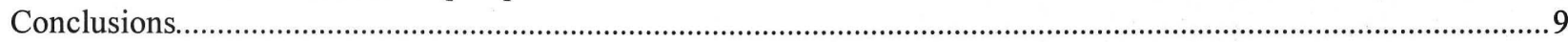

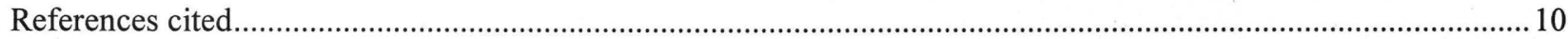

\section{FIGURES}

1. Index map of the Ozark Mountains region showing quadrangles studied under CUSMAP..................................2

2. East-west diagrammatic cross section across Harrison $1^{\circ} \times 2^{\circ}$ quadrangle showing drill holes and vertical positions of lithofacies slices relative to regional stratigraphy.....

. Map of the Tri-State district showing distribution of mined ores relative to pinchouts of underlying Northview and Chattanooga Shales. 


\title{
MAPS SHOWING LOCATIONS OF \\ KNOWN MISSISSIPPI VALLEY-TYPE DEPOSITS AND \\ OCCURRENCES IN THE OZARK MOUNTAINS REGION RELATIVE TO \\ LATE CAMBRIAN SHALY LITHOFACIES AND OTHER SHALES, MISSOURI, ARKANSAS, KANSAS, AND OKLAHOMA
}

\author{
By \\ James R. Palmer, Missouri Division of Geology and Land Survey, and \\ Timothy S. Hayes, U.S. Geological Survey
}

\section{CUSMAP}

These maps are the sixth publication in a folio of maps of the Harrison $1^{\circ} \times 2^{\circ}$ quadrangle, Arkansas and Missouri, prepared under the Conterminous United States Mineral Assessment Program (CUSMAP). Although they cover a much larger area than the Harrison quadrangle, they are included in the Harrison folio because they have the Harrison quadrangle in common and because they are outgrowths of work done for the Harrison and adjoining quadrangles in the CUSMAP. Previously published maps in the Harrison folio relate to the geochemistry of the subsurface carbonate rocks (Erickson and others, 1989), the geophysics of the basement terranes (McCafferty and others, 1989), the host-rock sedimentation, stratigraphy, and mineralization of the Caulfield district (Hayes and others, 1992), the mineral potential of the quadrangle (Pratt and others, 1993b), the lithofacies of Upper Cambrian rocks in the quadrangle (Hayes and others, in press), and the bedrock geology of the quadrangle (Middendorf and others, 1994, and in press).

\section{INTRODUCTION}

\section{PURPOSE OF COMPILATION}

The principal purpose of this publication is to relate the synthesized Paleozoic rock stratigraphic and sedimentologic data collected in recent CUSMAP projects to known Mississippi Valley-type deposits, as an aid to regional mineral assessment and prospecting.

Mississippi Valley-type (MVT) deposits in the Ozark Mountains region are galena-sphalerite(-barite) deposits hosted by shallow-water platform carbonate host rocks or locally by adjacent sandstones (Brockie and others, 1968; Snyder, 1968; Snyder and Gerdemann, 1968; Economic Geology, 1977; Heyl, 1983; Horrall and others, 1983; Rothbard, 1983; Sangster, 1983). A recurring question about MVT deposit genesis has been what the role of the host rocks is in the ore depositing process (Snyder and Gerdemann, 1968; Gerdemann and Myers, 1972; Amstutz and Fontboté, 1983; Rhodes and others, 1984).

Recent studies of the areal and stratigraphic distribution of these deposits, particularly in connection with the CUSMAP program, have shown that deposits tend to be located selectively within limestone host rocks (or in dolostones that were limestone prior to mineralization), particularly where these host rocks are adjacent to, and upsection from, pinchouts of aquitards, specifically shale and shaly limestone (Hayes and others, 1990; Palmer and Hayes, 1989). This publication, particularly map E, demonstrates this relationship for the part of the Ozark Mountains region that has been covered by CUSMAP (fig. 1). We will then use these data and maps to suggest locations that appear to have potential for discovery of new, large-tonnage MVT deposits.

Maps A-D show the sedimentation patterns of Upper Cambrian rocks in the Rolla, Springfield, Harrison, and Joplin $1^{\circ} \times 2^{\circ}$ quadrangles and adjoining areas at four successive time horizons. Map E shows the known MVT occurrences in all ages of host rocks in the region relative to pinchouts of shale or shaly carbonate lithofacies of Cambrian through Mississippian age and relative to faults. 


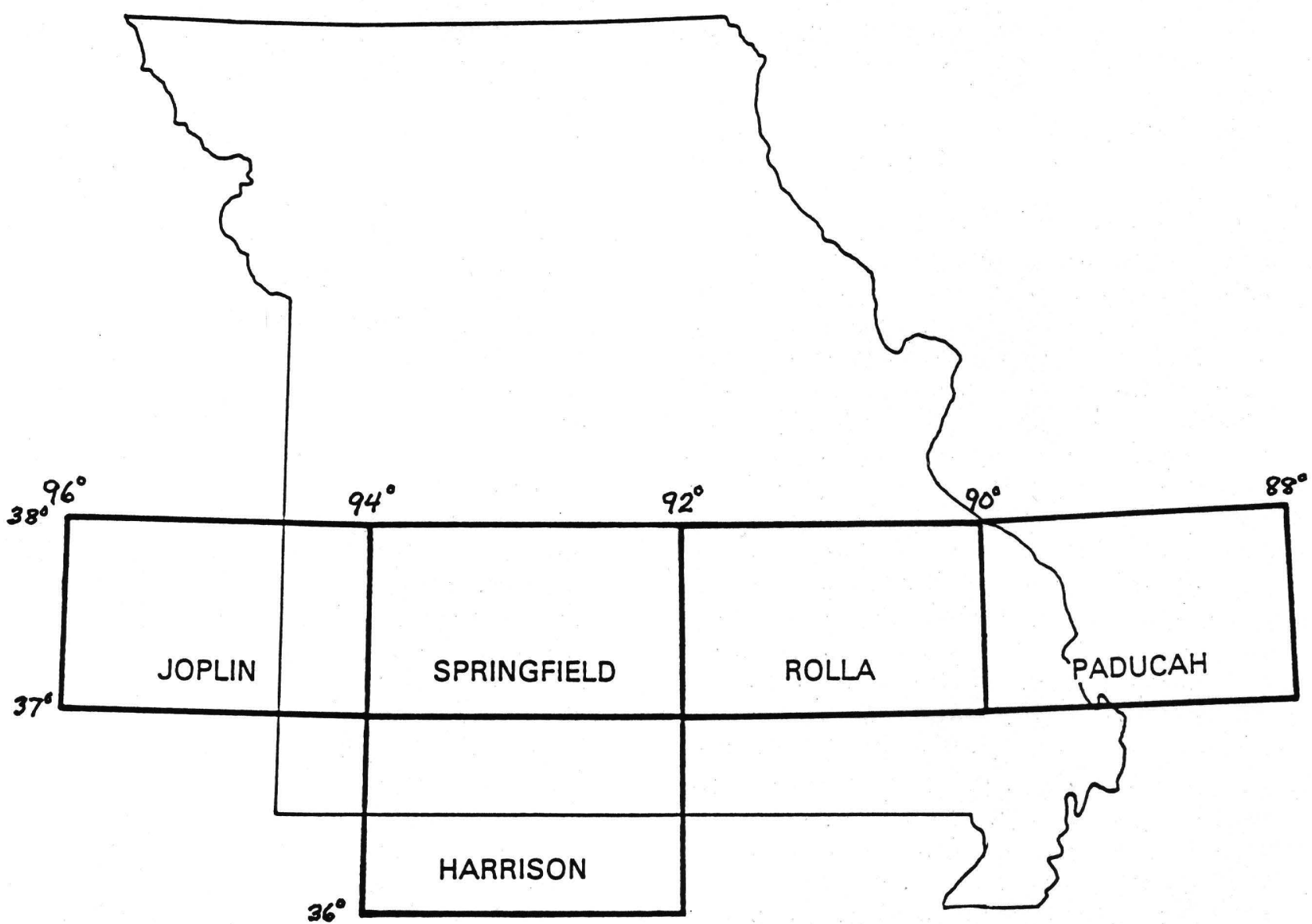

Figure 1. Index map of the Ozark Mountains region showing quadrangles studied under CUSMAP. 


\section{METHODS OF STUDY}

These maps are based on detailed macroscopic and binocular microscopic examination of drill cores, many of which were slabbed and the surfaces ground to less than 10 microns of relief. Drill cores were donated to the state core libraries of Missouri, Arkansas, Kansas, and Oklahoma by mineral exploration companies. The drill cores were logged by the authors, and their localities are shown on maps A-D. Sedimentologic information from core logging was supplemented by logging cuttings of oil tests, whose localities are also shown on maps $\mathrm{A}-\mathrm{D}$, and by examining downhole geophysical logs from these oil tests. We also logged cuttings or hydrochloric acidinsoluble residue fractions of carbonate rock from water-well sample collections stored in the State core libraries of Missouri and Arkansas. Localities of these holes are also shown dots on maps A-D. Other data presented here come from published lithofacies maps of the Rolla $1^{\circ} \times 2^{\circ}$ quadrangle resulting from the CUSMAP studies. Many of the drill hole sample collections examined here were also used by R. L. Erickson and coworkers of the U.S. Geological Survey in geochemical studies of the hydrochloric acidinsoluble residue fractions of carbonate rock from the Rolla, Springfield, Harrison, and Joplin $1^{\circ} \times 2^{\circ}$ quadrangles (Erickson and others, 1978, 1985, 1989, and 1990).

Maps A-D are "slice" maps, using a concept introduced in this area by Palmer in studies of the Springfield $1^{\circ} \times 2^{\circ}$ quadrangle (Palmer, 1986, 1991). A slice map shows the generalized distribution of lithofacies in a 10 -ft-thick section in the interval between two well-marked stratigraphic horizons; the vertical location of the section is stated as a percent of the distance between the two horizons (fig. 2). Thus, each map illustrates depositional lithofacies along a somewhat irregular surface, not necessarily horizontal either now or at the time of sedimentation, projected to the map plane. For example, map A shows the distribution of lithofacies in a slice located 50 percent of the distance from the base of the Sullivan Siltstone Member of the Bonneterre Formation to the base of the Bonneterre Formation. With the assumption that depositional rates were relatively constant at any given location in the map area between the times of the bounding stratigraphic horizons, such maps approximate time slices through these stratigraphic sequences in order to present map views of depositional sedimentary environments at several successive times over the course of sedimentation. As with subsurface cross sections, slice maps interpolate lithofacies between drill holes. Descriptions of the mapped depositional lithofacies are given in the following section.

The four slice maps, maps $A-D$, have the Springfield and Harrison quadrangles in common but differ in their east-west coverage. Map A includes the Rolla quadrangle but not the Joplin quadrangle because rocks equivalent to the Bonneterre Formation in the Joplin quadrangle are sandstones of the Reagan Sandstone, or, farther west, Bonneterre-equivalent rocks are absent by nondeposition higher on the depositional paleoslope (Palmer, 1991; Hayes and others, in press). Maps B, C, and D include the Joplin quadrangle but omit the Rolla quadrangle because facies have not been mapped for the Cambrian rocks overlying the Bonneterre Formation in the Rolla quadrangle. The Paducah quadrangle is shown on figure 2 because it was a part of the CUSMAP in this region, but lithofacies data were not available in time to be included in the present compilation.

\section{DESCRIPTIONS OF MAPPED CAMBRIAN LITHOFACIES}

Maps A-D are four successive slices through the deposystem of Upper Cambrian carbonate rocks of the Ozark Mountains region. Because it was held that MVT ore deposits were localized by carbonate rock lithofacies in the Southeast Missouri lead district (Gerdemann and Myers, 1972), depositional lithofacies of Cambrian and other potential carbonate host rocks were mapped in each successive CUSMAP quadrangle evaluation across the region. This mapping resulted in the ability to compile the depositional history of the Late Cambrian virtually region-wide. In this mapping the carbonate rock nomenclature of Dunham (1960) was used. Lithofacies assemblage names follow common usage from earlier studies of these rocks (Howe, 1968; Larsen, 1977; Lyle, 1977; Palmer, 1986) or are for the interpreted depositonal environment. Lithofacies assemblages of slice maps A-D are described in the following paragraphs, modified slightly from Hayes and others (in press). 


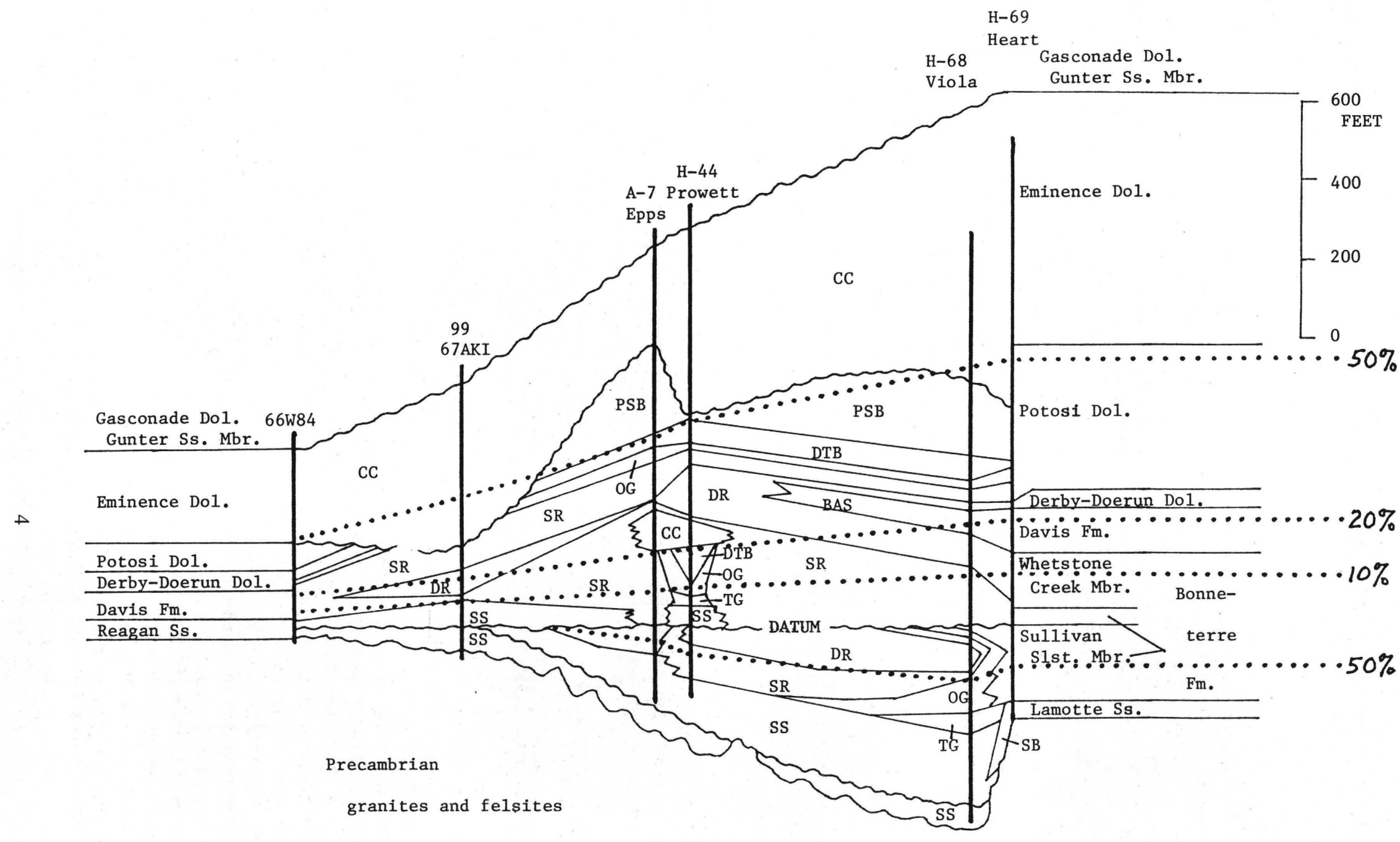

Figure 2. East-west diagrammatic cross section across Harrison $1^{\circ} \times 2^{\circ}$ quadrangle showing drill holes and vertical positions of lithofacies slices (heavy dotted line) relative to regional stratigraphy and lithofacies, from cross section $B-B^{\prime}$ (stratigraphy) of Hayes and others (in press). Dol., Dolomite; Fm, Formation; Mbr., Member; Slst., Siltstone; Ss., Sandstone. Lithofacies: BAS, basinal facies; CC, crystalline carbonate facies; DR, deep-ramp facies; DTB, digitate-thrombolite stromatolite boundstone facies; OG, ooid grainstone facies; PSB, planar stromatolite boundstone facies; SB, basement-clast sedimentary breccia; SR, shallow-ramp facies; SS, sandstone; TG, transitional grainstone facies. 


\section{MARINE QUARTZ SANDSTONE FACIES}

The marine quartz sandstone facies is light-gray or white, crossbedded sandstone consisting of fine to coarse, well-rounded, frosted quartz grains; mediumto dark-gray, burrowed sandstone consisting of fine to coarse, well-rounded quartz grains, but locally rich in mud (wacke); and quartzose sandstone-siltstone interbedded with green, blue, and dark-gray shale. Generally the facies is gradational into overlying or underlying "transitional" carbonate grainstones, which, in turn, grade into any of the shallow-ramp, deep-ramp, basinal, ooid grainstone, digitate-thrombolite stromatolite boundstone, or planar stromatolite and burrowed carbonate mudstone facies.

\section{SHALLOW-RAMP FACIES}

The shallow-ramp facies is medium- to darkbrown mudstone-wackestone interbedded with packstone-grainstone, and consisting of horizontally burrowed mudstone to wackestone interbedded with ooid-skeletal packstone and grainstone. The facies contains rare interbeds of dark-green shale and brown intraclast conglomerate wackestone to packstone.

\section{DEEP-RAMP FACIES}

The deep-ramp facies is brown to gray, limey siltstone and dolosiltstone containing rhythmic flaser, lenticular, and wavy bedding (ribbon rock). Beds consist of cyclic alternations of basal, very fine grainstone, grading upward to lime mudstone, capped by thin shale. Dark-green shale interbeds may make up 50 percent of the thickness; isolated, medium to thick interbeds of intraclast conglomeratic wackestone to packstone are common.

\section{BASINAL FACIES}

The basinal facies is dark-green, blue, and bluegray shale, containing less than 10 percent by thickness of thin to thick interbeds of limestone or dolostone intraclast conglomeratic wackestone to packstone, and minor thin interbeds of sandstone.

\section{OOID GRAINSTONE FACIES}

The ooid grainstone facies is dark- to light-brown ooid grainstone, either limestone or dolostone. Grainstones are crossbedded locally and only rarely bur- rowed. Ooid grainstones of the post-Bonneterre Cambrian include both ooid-dominant rocks and indeterminant grain-dominant rocks and are light medium brown to dark brown. All post-Bonneterre Cambrian ooid grainstone-facies rocks are dolostones.

\section{DIGITATE-THROMBOLITE STROMATOLITE BOUNDSTONE FACIES}

This facies is the digitate stromatolite boundstone facies as described in Larsen (1977, p. 411-414): bedded grainstone to thrombolite cycles consisting of a base of ooid wackestone, packstone, or grainstone as thick as about $2 \mathrm{ft}$, overlain by nonlaminated microbial, bound mudstone-wackestone 1-6 ft thick, having a clotted fabric in digitate or columnal forms. Thrombolitic parts of these cycles commonly have a branching habit. These rocks may change upwards to laminated (stromatolitic) columns, the digitate stromatolite of Larsen (1977).

\section{PLANAR STROMATOLITE BOUNDSTONE AND BURROWED CARBONATE MUDSTONE FACIES}

This is the same facies as that named and described by Howe (1968). In drill cores from this study the facies consists of shoaling-upward sequences $2-15 \mathrm{ft}$ thick, having a scoured or stylolitized base followed upward by lithoclast or oncolite grainstone, and in turn followed by thrombolite or digitate-stromatolite boundstones containing grainy internal sediments. Cycle tops consist of interbeds of cryptalgalaminated boundstones, hemispheroidal boundstones, and very thin, graded beds of fine carbonate grainstone grading up to mudstone. Mudstones are commonly burrowed extensively. Hemispheroidal boundstones or grainstone-mudstone graded beds may show desiccation cracks.

\section{CONTROLS BY}

\section{SEDIMENTARY ROCK PATTERNS ON MISSISSIPPI VALLEY-TYPE MINERALIZATION: EXPERIENCE OF THE OZARK MOUNTAINS CUSMAP STUDIES}

Earlier workers in the Southeast Missouri district thought that there was a strong control on lead-zinc sulfide ore deposition by the carbonate depositional lithofacies, in particular the limestone-dolostone 
interface (Snyder, 1968, p. 278). This interface, the presence of "brown rock" dolomite (Lyle, 1977), and the presence of digitate stromatolite boundstone facies (Larsen, 1977; Lyle, 1977) were considered to be three of five diagnostic criteria favorable for the presence of MVT deposits in the Rolla CUSMAP assessment (Pratt, 1981; Pratt and others, 1984). A fourth criterion was anomalous concentrations of a suite of metals found in the hydrochloric acidinsoluble residues of carbonate rocks. This suite of metals consists of lead, zinc, copper, silver, cobalt, nickel, arsenic, and molybdenum - the same metals that make up the MVT ores. Metals concentrations in insoluble residues are anomalous in a halo that is miles wide, enclosing all of the ores of the Southeast Missouri lead district in the Bonneterre Formation of the Rolla quadrangle (Erickson and others, 1978). The term "MVT suite" will be used for the eight elements listed above. These four criteria appeared to be valid for the Rolla quadrangle, but over the course of succeeding CUSMAP studies our understanding of the importance of lithofacies gradually changed, and with it our approach to the resource assessments.

In the Springfield quadrangle the MVT-suite metal anomalies in insoluble residues of carbonate rocks (Erickson and others, 1985, 1991) were mostly within the post-Bonneterre Cambrian carbonates, instead of within the Bonneterre. Digitate stromatolite boundstones are almost absent from the Bonneterre Formation (map A), but during the deposition of the lower half of the post-Bonneterre Cambrian sediments (represented by the 10,20, and 50 percent thickness slices-maps B, C, and D), the narrow facies belt of digitate stromatolite boundstones prograded both east and west across more than twothirds of the quadrangle (compare fig. 2 of Hayes and others, in press). Brown-rock dolomite is also spread quadrangle-wide within the post-Bonneterre Cambrian carbonates. Therefore the lithofacies criteria used in the Springfield assessment were simply to recognize all rocks that are now dolostone as prospective, though notably excluding the undolomitized deep ramp and basinal rocks of the Cambrian section.

By the time of the Harrison CUSMAP evaluation, we had begun to see that the areas containing the strongest insoluble-residue metal anomalies were adjacent to the pinchouts of the impermeable, undolomitized basinal and deep ramp shaly lithofacies. Consequently the key lithofacies criterion used in the Harrison assessment was not a particular lithofacies, but rather "a zone of abrupt changes in depositional lithofacies at ramp margins-specifically, a change from any permeable facies to impermeable shaly ramp and basinal facies" (Pratt and others, 1993b, p. $5)$. The presence or proximity of a limestone-dolostone interface was still used as a second diagnostic lithofacies criterion.

Finally, we undertook the assessment of the Joplin CUSMAP quadrangle, where one source of data for known deposits was a map by Brockie and others (1968), reproduced here as figure 3. It shows clearly that Tri-State ores occurred where neither the Devonian Chattanooga Shale nor the Lower Mississippian Northview Shale was present in thicknesses of $10 \mathrm{ft}$ or more beneath the Upper Mississippian limestone host rocks. Although the Tri-State ore bodies surround central core zones of early ore-stage hydrothermal dolomite, there is no evidence of dolomitization on a regional scale comparable to that in southeastern Missouri; hence, in the Joplin assessment of Mississippian carbonates, there were no regional limestone-dolostone interfaces. In short, as far as we could determine, the primary lithologic control on ore deposition in the Tri-State district was not the depositional lithofacies of the host rock itself, but simply the presence of a window through the impermeable shales beneath the limestone host rocks (see Pratt and others, 1993a). Now, with reference to the Southeast Missouri district, the analogous concept is that the ores of the Southeast Missouri district occur adjacent to, and upsection from, the pinchout of the impermeable basinal and deep ramp shaly facies of the Bonneterre Formation itself (map E).

This concept of shale edges and windows is not new; it was first suggested for the Tri-State Chattanooga pinchout by Smith and Siebenthal (1907), was widely used in the Tri-State district as indicated by Brockie and others (1968), and more recently has been championed by Ernest Ohle (oral commun., 1989) for the Southeast Missouri district. What is new is the revised view of the relation between Cambrian depositional lithofacies and MVT ores. We believe that there is no uniquely favorable lithofacies; there are only the unfavorable, still limy, shaly, deep-ramp and basinal facies aquitards. Their edges, where mineralizing fluids could have escaped upwards, are prospective for MVT deposits in rocks 100-300 ft upsectionward. 


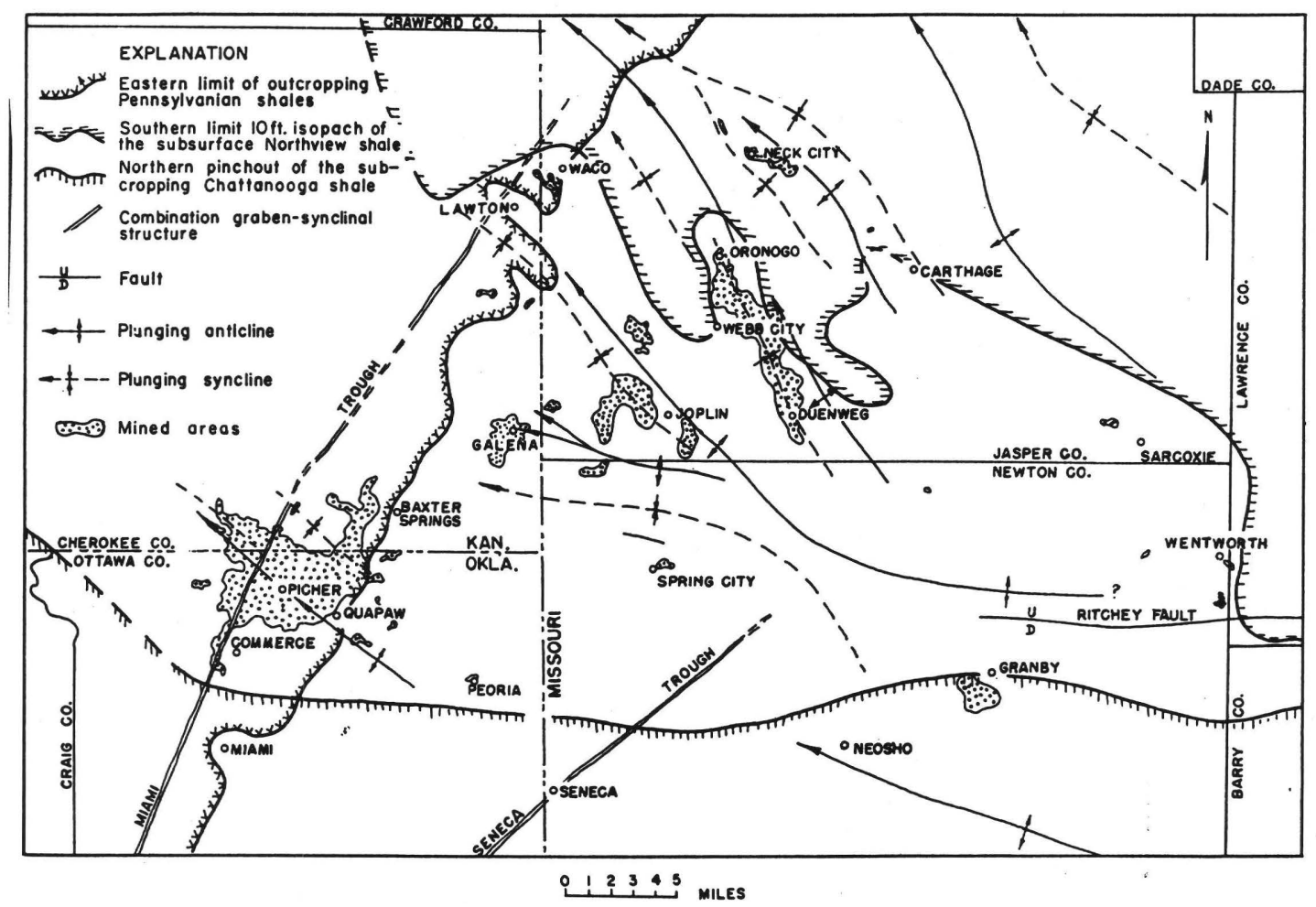

Figure 3. Map of the Tri-State district (Kansas-Missouri-Oklahoma) showing distribution of mined ores relative to pinchouts of underlying Northview and Chattanooga Shales; from Brockie and others (1968), figure 1. Reprinted by permission. 


\section{DISCUSSION OF MAPS}

\section{CAMBRIAN LITHOFACIES AQUITARDS}

Maps A-D show the distribution of depositional lithofacies in Cambrian rocks of the Ozark region; specifically, they show distributions of basinal and deep-ramp lithofacies, particularly where those rocks are undolomitized. These facies in these areas were aquitards at the time of region-wide movement of MVT ore fluids (Palmer and Hayes, 1989; Palmer and others, 1990).

\section{MVT DEPOSITS AND OCCURRENCES RELATIVE TO AQUITARD EDGES AND FAULTS}

Map E summarizes the information about Cambrian rock aquitards and adds additional aquitards upsection, specifically the Chattanooga and New Albany Shales (Devonian) and the Northview Shale (Mississippian). Also on map E are the known MVT deposits and occurrences, and faults, compiled from earlier CUSMAP studies and numerous other sources.

Map E shows that the large-tonnage MVT deposits of the region occur adjacent to pinchouts of shales and shaly limestone aquitards. Most of these large deposits also occur 100-300 ft upsection from the pinchouts. Map E also shows that most deposits of the central Missouri barite district occur in an area where there are no underlying shaly aquitards.

Upwelling fluids are the common thread between the large-tonnage deposits, adjacent to and upsection from shale pinchouts, and the other MVT deposits of the region. All of the Ozark region deposits occur where ore fluids could escape upwards, through or around the aquitards. In the Old Lead Belt and at Indian Creek in the Southeast Missouri district, much ore occurred in the Bonneterre, adjacent to, but not upsection from, a shale pinchout, but above places where the Lamotte Sandstone pinched out against buried Precambrian-rock hills (Snyder and Gerdemann, 1968). Those were places where ore fluids had to escape upwards around the low-permeability basement knobs. Many other ore deposits of the region occur where faults provided a break through the shaly aquitards. An example is the Northern Arkansas district where the association of ores with faults like the Rush Creek and Cold Spring faults has been well documented (McKnight, 1935). Additional ores occur where the rocks beneath paleosinkholes collapsed down through the shaly aquitards. An example in the Harrison quadrangle is the Alice mine in the Caulfield district, Missouri, probably in the collapse breccia pipe beneath a paleosinkhole (Hayes and others, 1992).

In short, explorationists in this region need to find the places where ore solutions could escape upwards. Probably the best model for a vast, interconnected fluid flow system covering all of the Ozark Mountains region, and employing all different kinds of vertical permeability to move upwards, is an artesian-driven flow system. With the assumption of regionwide artesian pressures, the ore fluids not only could have escaped upwards, they had to.

\section{DISCUSSION AND IDENTIFICATION OF PROSPECTIVE AREAS}

Plumlee and others (1994) have provided further explanation for why the large MVT deposits of the Ozarks occur where artesian-driven fluids could have escaped upwards at shale or shaly carbonate aquitard edges or through windows through the shales. They found, using reaction-path modeling in which fluid and rock compositions were derived from years of detailed geochemical and fluid-inclusion studies, that both Southeast Missouri and Tri-State ores formed where deep subsurface brines mixed. One such brine is common to both of the giant districts, but a second brine is distinct within the Southeast Missouri district, and a third may be distinct within the Tri-State district. In these cases, the mixing of fluids from two different aquifer levels was facilitated by upwelling under artesian pressure, and the upwelling was facilitated by the pinchout of a shaly confining unit.

Our work has shown that hydrothermal dolomites, like metals anomalies in carbonate-rock insoluble residues, record at least the presence or passage of an ore-stage hydrothermal brine, although, as above, two different brine components may have been required for large-tonnage ores to form. No hydrothermal dolomite crustifications have been found north of a line that crosses through both the Southeast Missouri and Central Missouri barite districts. The line is the trace of a surface that crosses downward through strata to the north, and, because the sedimentary rocks are nearly horizontal, generally dips very gently northward. South of and below this surface hydrothermal dolomite crusts, correlatable with ore-stage dolomites of the Southeast Missouri, Northern Arkansas, and Tri-State district ores, occur 
within carbonate rocks having many different types of secondary porosity through all the preserved Phanerozoic section except the shales and shaly aquitards. North of and above this surface the correlatable hydrothermal dolomite crusts may occur in a few rare barite- or sphalerite-mineralized secondary porosity sites. They are not found in most of the mapped barite occurrences shown on map E.

Map E also shows what is here interpreted as a regional-scale zonation of MVT deposit types: a belt of zinc-dominant deposits in the south, a belt of leaddominant deposits across the central part of the map area, and a belt of barite-dominant deposits across the north. That such a zonation might be present across the Ozark region was first recognized by Leach (1973). The Southeast Missouri district is dominated by lead throughout its extent, and the Tri-State district is dominated by zinc throughout. We speculate that the regional belts of MVT deposit types - zinc, lead, and barite, from south to north-represent the surface intercepts of parallel zones of these deposit types, and that these zones dip gently northward and are parallel to the upper surface of the zone of correlatable hydrothermal dolomite crusts. All of this is consistent with multiple evidence that ore solutions migrated regionally from south to north (Leach and Rowan, 1986).

Map E can now be used to identify several additional prospective areas across the region. First are the windows through the Northview and Chattanooga Shales to the northwest from the known TriState district. Though the location is nowhere available in published literature, it is widely known that mineralization has been discovered in Mississippian host rocks near the town of Oswego, Kansas, in the window nearest to and northwest from the known district (Pieter Berendsen and R.D. Hagni, oral commun., 1989). Moving eastward, the windows through all of the shales, stretching northwestward from the known Northern Arkansas zinc district toward the Tri-State district, appear to be prospective, but the likeliest host rocks for large-tonnage mineralization would have been the limestone-dominated Mississippian rocks, which have largely been removed by erosion.

Northward from there, in the Springfield and, perhaps, the Jefferson City quadrangles, about $20 \mathrm{mi}$ east of Springfield and extending to the north, there is an eastward pinchout of undolomitized Davis Formation deep- and shallow-ramp lithofacies rocks (maps B and E; see also Palmer, 1991, fig. 8). The rocks adjacent to and upsection from this pinchout also contain strongly anomalous amounts of MVT-suite metals in carbonate-rock insoluble residues (holes S11, NS5, and NS6 of Erickson and others, 1985). Palmer (1991) pointed out that the facies tract along this pinchout in post-Bonneterre Cambrian rocks is very similar to that in the Bonneterre along the Viburnum Trend. On the basis of these assessment criteria, this shale edge appears to be highly prospective for large-tonnage, possibly lead-dominant MVT deposits.

Both Bonneterre Formation and Davis Formation undolomitized deep-ramp and basinal facies rocks pinch out westward against the Lebanon Arch of the central Springfield and (perhaps) Jefferson City quadrangles. Most of this pinchout trend is not accompanied by strong metals anomalies in insoluble residues in either the Bonneterre or post-Bonneterre Cambrian rocks (Erickson and others, 1985). Though on the shale-edge criterion it is prospective, it cannot be considered as favorable as the Davis pinchout zone on the west side of the Lebanon Arch.

Finally, in the Rolla quadrangle two extensions of the pinchout of undolomitized Bonneterre rocks appear prospective. The more obvious of the two extends southward and southwestward from the known ores along the Viburnum Trend. This is an area of currently active prospecting. The less obviously prospective area is the limestone-dolostone interface southeast of the "island" of dolomitized Bonneterre that encircles the St. Francois Mountains. The transition there is from whiterock dolostones of the Bonneterre (Lyle, 1977; Howe, 1968) to pink or red Taum Sauk limestones ( $€ b t$ of map E; Howe, 1968; Frank, 1981). The limestone-dolostone interface there does have areas of accompanying metals anomalies in carbonate-rock insoluble residues (Erickson and others, 1978).

The westward pinchouts of undolomitized Davis Formation on the eastern Joplin and Kansas City quadrangles (map E) are not considered a prospective zone because those pinchouts are gradational lateral transitions into equivalent sandstone or siltstone lithologies of the Reagan Sandstone (Palmer, 1991; Hayes and others, in press).

\section{CONCLUSIONS}

MVT ore deposits occurred within the Ozark region only at places where a component of ore fluids escaped aquitard confinement upwards, probably under artesian pressure. Facies-controlled vertical permeability is the cause of apparent lithofacies 
control of the MVT deposits of the Bonneterre Formation in the Southeast Missouri district. Much of the ore of both of the major MVT districts in the Ozarks occurs adjacent to, and upsection from, the pinchout of a shaly unit. Shale-edge maps, particularly where they are combined with the trace metals in insoluble-residues maps like those of Ralph Erickson and his coworkers on the Rolla, Springfield, Harrison, and Joplin CUSMAP quadrangles, should be a useful regional prospecting tool as well as a valid method for evaluation of regional-scale potential for MVT deposits.

\section{REFERENCES CITED}

Amstutz, G.C., and Fontboté, L., 1983, Observations on the genesis of stratabound $\mathrm{Pb}-\mathrm{Zn}$-(F-Ba-) deposits in carbonate rocks, in Kisvarsanyi, Geza, Grant, S.K., Pratt, W.P., and Koenig, J.W., eds., International conference on Mississippi Valleytype lead-zinc deposits: University of MissouriRolla, 1982, Proceedings, p. 536-545.

Ball, S.H., and Smith, A.F., 1903, The geology of Miller County: Missouri Bureau of Geology and Mines, 2nd series, v. 1, $207 \mathrm{p}$.

Beveridge, T.R., and Clark, E.L., 1952, A revision of the early Mississippian nomenclature in western Missouri, in Guidebook, 16th Regional Field Conference, Kansas Geological Survey, westcentral Missouri: Missouri Geological Survey and Water Resources Report of Investigations 13, p. 71-80.

Brobst, D.A., and Wagner, R.J., 1967, Barite, in Mineral and water resources of Missouri: Missouri Geological Survey, 2nd series., v. 43, p. 99-106.

Brockie, D.C., Hare, E.H., Jr., and Dingess, P.R., 1968, The geology and ore deposits of the TriState district of Missouri, Kansas, and Oklahoma, in v. 1 of Ridge, J.D., ed., Ore deposits of the United States, 1933-1967 (The Graton-Sales Volume): New York, American Institute of Mining, Metallurgical, and Petroleum Engineers, p. 400-430.

Dunham, R.J., 1960, Classification of carbonate rocks according to depositional texture: American Association of Petroleum Geologists Memoir 1, p. 108-121.

Economic Geology, 1977, An issue devoted to the Viburnum Trend, southeast Missouri: Economic Geology, v. 72, no. 3, p. 337-490.
Erickson, R.L., Chazin, B., and Erickson, M.S., 1989, Summary geochemical maps of the Harrison $1^{\circ} \times 2^{\circ}$ quadrangle, Missouri and Arkansas: U.S. Geological Survey Miscellaneous Field Studies Map MF-1994-A, scales 1:250,000 and 1:500,000.

Erickson, R.L., Erickson, M.S., Mosier, E.L., and Chazin, Barbara, 1985, Summary geochemical maps of the Springfield $1^{\circ} \times 2^{\circ}$ quadrangle, Missouri: U.S. Geological Survey Miscellaneous Field Studies Map MF-1830-A, scale 1:500,000. 1991, Geochemical studies of subsurface carbonate rocks, in Martin, J.A., and Pratt, W.P., eds., Geology and mineral-resource assessment of the Springfield $1^{\circ} \times 2^{\circ}$ quadrangle, Missouri: U.S. Geological Survey Bulletin 1942, p. 51-52.

Erickson, R.L., Mosier, E.L., Folger, H.W., Bullock, J.H., Jr., Berendsen, Pieter, and Daly [Daily], Mary, 1990, Summary geochemical maps of the Joplin $1^{\circ} \times 2^{\circ}$ quadrangle, Kansas and Missouri: U.S. Geological Survey Miscellaneous Field Studies Map MF-2125-A, scales 1:250,000 and 1:500,000.

Erickson, R.L., Mosier, E.L., and Viets, J.G., 1978, Generalized geologic and summary geochemical maps of the Rolla $1^{\circ} \times 2^{\circ}$ quadrangle, Missouri: U.S. Geological Survey Miscellaneous Field Studies Map MF-1004-A, scale 1:250,000.

Gerdemann, P.E., and Myers, H.E., 1972, Relationship of carbonate facies patterns to ore distribution and to ore genesis in the Southeast Missouri lead district: Economic Geology, v. 67, p. 426433.

Hayes, T.S., Palmer, J.R., and Krizanich, G.W., 1992, Cross sections of Lower Ordovician carbonate depositional lithofacies and Mississippi Valleytype zinc- and iron-sulfide mineralization in the Caulfield district, east-central part of the Harrison $1^{\circ} \times 2^{\circ}$ quadrangle, Arkansas and Missouri: U.S. Geological Survey Miscellaneous Field Studies Map MF-1994-C, scales 1:2400 and $1: 1200$.

Hayes, T.S., Palmer, J.R., Pratt, W.P., Krizanich, G.W., Whitfield, J.W., and Seeger, C.M., in press, Cross sections showing stratigraphic and depositional lithofacies of Upper Cambrian rocks and the relation of lithofacies to potential for Mississippi Valley-type mineralization in the Harrison $1^{\circ} \times 2^{\circ}$ quadrangle, Missouri and Arkansas: U.S. Geological Survey Miscellaneous Field Studies Map MF-1994-E, scale 1:500,000. 
Hayes, T.S., Palmer, J.R., and Rowan, E.L., 1990, Correlation of hydrothermal dolomite generations across the Mississippi Valley-type mineralizing system of the Ozark ragion, in Pratt, W.P., and Goldhaber, M.B., eds., U.S. Geological Survey-Missouri Geological Survey Symposium, Mineral-Resource Potential of the Midcontinent, St. Louis, Missouri, April 11-12, 1989, Program and abstracts: U.S. Geological Survey Circular 1043, p. 10.

Heyl, A.V., 1968, Minor epigenetic, diagenetic, and syngenetic sulfide, fluorite, and barite occurrences in the Central United States: Economic Geology, v. 63, p. 585-594.

1983, Geologic characteristics of three major Mississippi Valleydistricts, in Kisvarsanyi, Geza, Grant, S.K., Pratt, W.P., and Koenig, J.W., eds., International conference on Mississippi Valleytype lead-zinc deposits: University of MissouriRolla, 1982, Proceedings, p. 27-60.

Horrall, K.B., Hagni, R.D., and Kisvarsanyi, Geza, 1983, Mineralogical, textural, and paragenetic studies of selected ore deposits of the Southeast Missouri lead-zinc-copper district and their genetic implications, in Kisvarsanyi, Geza, Grant, S.K., Pratt, W.P., and Koenig, J.W., eds., International conference on Mississippi Valley-type lead-zinc deposits: University of Missouri-Rolla, 1982, Proceedings, p. 289-316.

Howe, W.B., 1968, Planar stromatolite and burrowed carbonate mud facies in Cambrian strata of the St. Francois Mountain area: Missouri Geological Survey and Water Resources Report of Investigations $41,113 \mathrm{p}$.

Kisvarsanyi, Geza, 1977, The role of Precambrian igneous basement in the formation of stratabound lead-zinc-copper deposits in southeast Missouri: Economic Geology, v. 72, p. 435-442.

1982, Regional depositional facies of the Cambrian Bonneterre Formation, Rolla $1^{\circ} \times 2^{\circ}$ quadrangle, Missouri: U.S. Geological Survey Miscellaneous Field Studies Map MF-1002-I, scale $1: 250,000$.

Larsen, K.G., 1977, Sedimentology of the Bonneterre Formation, southeast Missouri: Economic Geology, v. 72, p. 408-419.

Leach, D.L., 1973, A study of the barite-lead-zinc deposits of central Missouri and related mineral deposits in the Ozark region: Columbia, University of Missouri, Ph.D. dissertation, 186 p.
1980, Nature of mineralizing fluids in the barite deposits of central and southeast Missouri: Economic Geology, v. 75, p. 1168-1180.

Leach, D.L., and Rowan, E.L., 1986, Genetic link between Ouachita foldbelt tectonism and the Mississippi Valley-type lead-zinc deposits of the Ozarks: Geology, v. 14, p. 931-935.

Lyle, J.R., 1977, Petrography and carbonate diagenesis of the Bonneterre Formation in the Viburnum Trend area, southeast Missouri: Economic Geology, v. 72, p. 420-434.

Mather, W.B., 1947, Barite deposits of central Missouri: American Institute of Mining and Metallurgical Engineers Transactions, v. 173, p. 94108.

McCafferty, A.E., Cordell, Lindrith, and Bracken, R.E., 1989, Geophysical maps and interpretation of basement terrane in the Harrison $1^{\circ} \times 2^{\circ}$ quadrangle, Missouri and Arkansas: U.S. Geological Survey Miscellaneous Field Studies Map MF1994-B, scale 1:250,000.

McCauley, J.R., and Smith, D.C., in press, Bedrock geologic map of the Joplin $1^{\circ} \times 2^{\circ}$ quadrangle, Kansas and Missouri: U.S. Geological Survey Miscellaneous Investigations Series Map I2426-B, scale 1:250,000.

McCracken, M.H., 1971, Structural features map of Missouri: Missouri Geological Survey and Water Resources Report of Investigations 49, 100 p., map scale 1:500,000.

McKnight, E.T., 1935, Zinc and lead deposits of northern Arkansas: U.S. Geological Survey Bulletin $853,311 \mathrm{p}$.

McKnight, E.T., and Fischer, R.P., 1970, Geology and ore deposits of the Picher field, Oklahoma and Kansas: U.S. Geological Survey Professional Paper 588, $165 \mathrm{p}$.

Middendorf, M.A., Thomson, K.C., Easson, G.L., and Sumner, H.S., 1987, Bedrock geologic map of the Springfield $1^{\circ} \times 2^{\circ}$ quadrangle, Missouri: U.S. Geological Survey Miscellaneous Investigations Series Map I-2029, scale 1:250,000.

Middendorf, M.A., Thomson, K.C., Robertson, C.E., Whitfield, J.W., Glick, E.E., Bush, W.V., Haley, B.R., and McFarland, J.D., III, 1994, Bedrock geologic map of the Harrison $1^{\circ} \times 2^{\circ}$ quadrangle, Missouri and Arkansas: U.S. Geological Survey Open-File Report 94-430, scale 1:250,000, 15 p. text. 
in press, Geologic map of the Harrison $1^{\circ} \times 2^{\circ}$ quadrangle, Missouri and Arkansas: U.S. Geological Survey Miscellaneous Investigations Series Map I-2548, scale 1:250,000.

Miller, M.H., 1982, Mines, prospects, and occurrences of metallic minerals in the Rolla $1^{\circ} \times 2^{\circ}$ quadrangle, Missouri: U.S. Geological Survey Miscellaneous Field Studies Map MF-1005-B, scale 1:250,000.

Palmer, J.R., 1986, Lithofacies maps of the Cambrian carbonates, Springfield $1^{\circ} \times 2^{\circ}$ quadrangle, Missouri: Missouri Geological Survey Open-File Map OFM-85-230-GI, scale 1:500,000.

1991, Distribution of lithofacies and inferred depositional environments in the Cambrian System, in Martin, J.A., and Pratt, W.P., eds., Geology and mineral-resource assessment of the Springfield $1^{\circ} \times 2^{\circ}$ quadrangle, Missouri: U.S. Geological Survey Bulletin 1942, p. 9-38.

Palmer, J.R., and Hayes, T.S., 1989, Late Cambrian lithofacies and their control on the Mississippi Valley-type mineralizing system in the Ozark region, in Schindler, K.S., ed., USGS Research on Mineral Resources-1989, Fifth Annual V.E. McKelvey Forum on Mineral and Energy Resources, Program and abstracts: U.S. Geological Survey Circular 1035, p. 51-53.

Palmer, J.R., Hayes, T.S., Seeger, C.M., Krizanich, G., Werdon, M., and Whitfield, J.W., 1990, Application of Cambrian lithofacies mapping in the Springfield, Harrison, and Joplin CUSMAP assessments for Mississippi Valley-type deposits, in Pratt, W.P., and Goldhaber, M.B., eds., U.S. Geological Survey-Missouri Geological Survey Symposium, Mineral-Resource Potential of the Midcontinent, St. Louis, Missouri, April 11-12, 1989, Program and abstracts: U.S. Geological Survey Circular 1043, p. 26.

Plumlee, G.S., Leach, D.L., Hofstra, A.H., Landis, G.P., Rowan, E.L., and Viets, J.G., 1994, Chemical reaction path modeling of ore deposition in Mississippi Valley-type $\mathrm{Pb}-\mathrm{Zn}$ deposits of the Ozark region, U.S. Midcontinent: Economic Geology, v. 89, p. 1361-1383.

Pratt, W.P., ed., 1981, Metallic mineral-resource potential of the Rolla $1^{\circ} \times 2^{\circ}$ quadrangle, Missouri, as appraised in September 1980: U.S. Geological Survey Open-File Report 81-518, 77 p.

1982, Map showing geologic structures in the Rolla $1^{\circ} \times 2^{\circ}$ quadrangle, Missouri: U.S. Geological Survey Miscellaneous Field Studies Map MF-1000-A, scale 1:250,000. comp., 1993, Maps showing areal extent of selected Paleozoic shales in the northern Midcontinent, U.S.A.: U.S. Geological Survey Miscellaneous Field Studies Map MF-1835-H, scale $1: 1,000,000$.

Pratt, W.P., Erickson, R.L., Kisvarsanyi, E.B., and Wharton, H.M., 1984, Maps showing areas of significant metallic mineral-resource potential in the Rolla $1^{\circ} \times 2^{\circ}$ quadrangle, Missouri, as appraised in September 1980: U.S. Geological Survey Miscellaneous Field Studies Map MF-1005A, scale 1:250,000.

Pratt, W.P., Hayes, T.S., Erickson, R.L., Berendsen, Pieter, and Kisvarsanyi, E.B., 1993a, Assessment of the Joplin $1^{\circ} \times 2^{\circ}$ quadrangle, Kansas and Missouri, for Mississippi Valley-type deposits and other minerals: U.S. Geological Survey Miscellaneous Field Studies Map MF-2125-E, scale $1: 250,000$.

Pratt, W.P., Hayes, T.S., Erickson, R.L., Kisvarsanyi, E.B., McFarland, M.C., Rueff, Ardel, Bush, W.V., Colton, G.W., and McFarland, J.D., III, 1993b, Mineral-resource potential of the Harrison $1^{\circ} \times 2^{\circ}$ quadrangle, Missouri and Arkansas: U.S. Geological Survey Miscellaneous Field Studies Map MF-1994-D, scales 1:250,000 and 1:500,000.

Rhodes, D., Lantos, E.A., Lantos, J.A., Webb, R.J., and Owens, D.C., 1984, Pine Point orebodies and their relationship to the stratigraphy, structure, dolomitization, and karstification of the Middle Devonian barrier complex: Economic Geology, v. 79, p. 991-1055.

Rothbard, D.R., 1983, Diagenetic history of the Lamotte Sandstone, southeast Missouri; in

Kisvarsanyi, Geza, Grant, S.K., Pratt, W.P., and Koenig, J.W., eds., International conference on Mississippi Valley-type lead-zinc deposits: University of Missouri-Rolla, 1982, Proceedings, $p$. 385-395.

Sangster, D.F., 1983, Mississippi Valley-type deposits-A geological mélange, in Kisvarsanyi, Geza, Grant, S.K., Pratt, W.P., and Koenig, J.W.,

eds., International conference on Mississippi Valleytype lead-zinc deposits: University of MissouriRolla, 1982, Proceedings, p. 7-19.

Smith, W:S.T., and Siebenthal, C.E., 1907, Description of the Joplin district: U.S. Geological Survey Geologic Atlas, Folio 148, 20 p., maps. 
Snyder, F.G., 1968, Geology and mineral deposits, Midcontinent United States, in v. 1 of Ridge, J.D., ed., Ore deposits of the United States, 1933-1967 (The Graton-Sales Volume): New York, American Institute of Mining, Metallurgical, and Petroleum Engineers, p. 258-325.

Snyder, F.G., and Gerdemann, P.E., 1968, Geology of the Southeast Missouri Lead district, in v. 1 of Ridge, J.D., ed., Ore Deposits of the United States, 1933-1967 (The Graton-Sales Volume): New York, American Institute of Mining, Metallurgical, and Petroleum Engineers, p. 327-358.
Thacker, J.L., and Anderson, K.H., 1979, Preliminary carbonate lithofacies maps of the Cambrian Bonneterre Formation, Rolla $1^{\circ} \times 2^{\circ}$ quadrangle, Missouri: U.S. Geological Survey Miscellaneous Field Studies Map MF-1002-C, scale 1:250,000.

Van Horn, F.B., and Buckley, E.R., 1905, The geology of Moniteau County: Missouri Bureau of Geology and Mines, 2nd series, v. 3, 104 p.

Wharton, H.M., 1987, Mines, prospects, and occurrences of metallic minerals and barite, Springfield $1^{\circ} \times 2^{\circ}$ quadrangle, Missouri: U.S. Geological Survey Miscellaneous Field Studies Map MF-1830-C, scale 1:250,000. 